\title{
ANALISIS METODE CARD SORT DALAM PEMBELAJARAN MUFRADAT BERBASIS PENDEKETAN KOGNITIF
}

\author{
Irvan Maulana Tamsil \\ e-mail: irvantamsil@rocketmail.com \\ Universitas Islam Negeri (UIN) Sunan Kalijaga Yogyakarta
}

\begin{abstract}
Abstrak: Tujuan penelitian ini adalah untuk menganalisa penggunaan metode card sort dalam pembelajaran mufradat berbasis pendekatan kognitif. Dalam penelitian ini, peneliti menggunakan metode penelitian kepustakaan. Hasil penelitian menunjukkan bahwa dalam pembelajaran mufradat berbasis pendekatan kognitif, guru memberikan kesempatan bagi siswa untuk berpikir, memahami, dan mengeksplorasi, karena pendekatan ini berbasis proses bukan berbasis hasil. Perilaku seseorang ditentukan oleh pemahamannya terhadap situasi yang terkait dengan tujuan pembelajaran. Proses pembelajaran tersebut membuat siswa menjadi lebih aktif (berpusat pada siswa). Dalam hal ini, guru sebagai fasilitator menggunakan metode card sort dalam proses pembelajaran, oleh karena itu siswa menjadi lebih antusias dan tidak merasa bosan dalam pembelajaran mufradat.
\end{abstract}

Kata Kunci: Metode card sort, mufradat, pendekatan kognitif, pembelajaran bahasa Arab.

\begin{abstract}
The purpose of this study is to analyze the using of card sort method in learning A rabic vocabulary based on cognitive approach. In this study, the researcher used was library research. The finding of this study indicated that in the learning Arabic vocabulary based on cognitive learning, teacher provided an opportunity for students to think, understand, and explore because this approach is proses-based, not product-based. Someone's behaviour is decided by his understanding about situation related to the learning objectives. The learning process supports students to be more active (student-centered). In this case, the teacher as a facilitator used a card sort method in learning process, thus, the students are more enthusiastic and do not feel bored in learning Arabic vocabulary.
\end{abstract}

Keywords: Card sort method, vocabulary, cognitive approach, Arabic language learning.

\section{PENDAHULUAN}

Bahasa Arab merupakan salah satu bahasa dunia, yang telah mengalami perkembangan sejalan dengan perkembangan sosial masyarakat dan ilmu pengetahuan. Bahasa Arab termasuk rumpun bahasa semit yaitu bahasa yang dipakai bangsa-bangsa yang tinggal disekitar sungai Trigis dan Furat, dataran Syiria dan jazirah Arabia (Timur Tengah) seperti bahasa Finisia, Assyiria, Ibrania, Arabia, Suryania, dan Babilonia (Rosyidi, 2009: 1). Bahasa Arab yang kini telah menjadi bahasa dunia internasional setelah Spanyol, memiliki andil besar dalam menumbuh kembangkan ilmu pengetahuan dan teknologi modern. Tren ini menujukkan adanya komunikasi aktif bangsa Arab dengan bangsa-bangsa yang eksis didunia ini. Kendati demikian bukan berarti 
mempelajari bahasa Arab suatu hal yang gampang bagi pelajar Arab itu sendiri sebagaimana orang asing mempelajarinya. Bahkan dikatakan bahwa orang Arab kadang-kadang merasakan mudah dalam mempelajari bahasa asing seperti, bahasa Inggris, Prancis, dan sebagainya, dibandingkan mereka mempelajari bahasanya sendiri. Hal ini disebabkan berbagai alas an, salah satu diantaranya adalah banyak mufradat yang memiliki nuansa arti dari suku kata, dan ini harus dikuasai oleh pembelajar bahasa (Zulhannan \& Rahayu, 2014:107-110).

Standar proses pendidikan adalah standar nasional pendidikan yang berkaitan dengan pelaksanaan pembelajaran pada satu satuan pendidikan untuk mencapai standar kompetensi lulusan (Peraturan Pemerintah No. 19 Tahun 2005 Bab 1 pasal 1 ayat 6). Proses pembelajaran yang terjadi di dalam kelas dilaksanakan sesuai dengan kemampuan dan selera guru. Padahal pada kenyataannya kemampuan guru dalam pengelolaan pembelajaran tidak merata sesuai dengan latar belakang pendidikan guru serta motivasi dan kecintaan merka terhadap profesinya. Ada guru yang dalam melaksanakan pengelolaan pembelajaranya dilakukan dengan sungguh-sungguh melalui perencanaan yang matang, dengan memanfaatkan seluruh sumber daya yang ada dan memperhatikan taraf perkembangan intelektual dan perkembangan psikologi belajar anak. Melalui standar proses pendidikan setiap guru dapat mengembangkan proses pembelajaran sesuai rambu-rambu yang ditentukan (Sanjaya, 2008: 4-5).

Mempelajari bahasa Arab tidaklah semudah yang dibayangkan dan pada kenyataannya orang Indonesia dalam mempelajari bahasa Arab membutuhkan waktu yang relatif lama karena bahasa Arab bukanlah bahasa Ibu yang dipakai dalam kegiatan sehari-hari. Selain itu, bahasa arab merupakan bahasa asing yang memiliki standar tinggi dan keindahan linguistik yang sudah diakui dunia internasional (Qomaruddin, 2017: 21). Unsur-unsur bahasa Arab secara garis besar mencakup ada empat yaitu: al-ashwat, al-huruf, al-qawa'id, dan al-mufradat. Masing-masing unsur bahasa Arab ini menjadi disiplin ilmu tersendiri, misalnya: al-mufradat banyak dikaji dan dituangkan dalam mu'jam-mu’jam al-lughah al-arabiyah (Maksudin \& Nurani, 2018: 96).

Salah satu komponen dalam bahasa Arab adalah mufradat. Ada anggapan bahwa perbendaharaaan mufradat yang memadai akan sangat membantu pembelajar bahasa Arab dalam menguasai bahasa tersebut khususnya empat kemahiran berbahasa. Oleh sebab itu, mufradat harus diajarkan dengan metode dan teknik yang baik agar dapat membantu memudahkan para pembelajar bahasa Arab dalam menambah perbendaharaan mufradat mereka (Qomaruddin, 2017: 21).

Mufradat adalah susunan huruf dalam bentuk kata benda (isim) dan kata kerja (fi'il), di samping bentuk huruf sendiri ada macam-macam (Maksudin \& Nurani, 2018: 97). Mufradat merupakan salah satu unsur terpenting dalam bahasa termasuk bahasa Arab, disamping kaidah tata bahasa atau ilmu nahwu (sintaksis), ilmu sorof (morfologi), dan ilmu ashwat (fonetik). Setiap bahasa termasuk bahasa Arab memiliki mufradat yang mempunyai fungsi, peran serta pengaruh yang besar dalam pembelajaran bahasa didalamnya, terlebih lagi mempelajari bahasa Arab bagi pelajar Indonesia berarti juga mempelajari bahasa asing, oleh karena itu mempelajari mufradat merupakan prasyarat dan tuntutan yang mendasari seseorang dalam menguasai bahasa kedua tersebut (Fajriyyah, 2015: 109).

Proses pembelajaran mestinya harus bergeser dari sekedar intruksional, hafalan, dan hanya menjadikan guru sebagai sumber tunggal pembelajaran. Sumber-sumber pembelajaran harus semakin beragam, bukan hanya guru atau buku, tetapi juga melalui proses ekplorasi melalui pengalaman 
hidup, interaksi dengan lingkungan fisik, interaksi dengan teman sebaya (Hartono, 2011: 48-49).

Mufradat merupakan hal yang sangat penting dalam pembelajaran bahasa Arab. Penggunaan mufradat yang tepat dalam sebuah kalimat dapat memahamkan makna terhadap pesan yang akan disampaikan melalui bahasa. Pembelajaran mufradat berkaitan dengan punguasaan makna katakata, serta digunakan pada tempat yang sesuai (Rosyidi, 2009: 54).

Pentingnya pembelajaran mufradat terhadap peningkatan dan pengembangan kemampuan siswa dalam berbahasa menyebabkan pembelajaran mufradat semakin mendesak untuk dilakukan secara lebih serius dan terarah. Hal ini disebabkan kenyataan di lapangan masih banyak dijumpai siswa yang mengalami kesulitan dalam melakukan pembelajaran bahasa Arab (Astuti, 2016: 178). Pembelajaran bahasa Arab kelas X Madrasah Aliyah terutama dalam penguasaan mufradat masih tergolong rendah. Berdasarkan observasi yang dilakukan peneliti, antusiasme dan keaktifan siswa terhadap pembelajaran bahasa Arab masih kurang. Hal ini terlihat saat kegiatan belajar mengajar siswa tidak fokus terhadap materi dan cenderung berkegiatan sendiri atau mengantuk (Suprihatin, Elmubarok, \& Busri, 2017: 40). Dalam hal ini, pembelajaran mufradat bahasa Arab siswa kelas X SMA Nurul Muslim hanya terfokus pada pemberian materi dari guru, sehingga seorang siswa mendapatkan mufradat yang didengarkannya dan di pahami dari ucapan guru saja, tanpa ada usaha dari pihak lain.

Belajar mengajar menggunakan pendekatan kognitif, khususnya bagi siswa yang sedang mengembangkan seluruh potensi psikologisnya, baik yang berdimensi afektif maupun psikomotor. Oleh karenanya, perkembangan kognitif siswa harus secara terarah, baik oleh orang tua atupun guru sangat penting (Syah, 2013: 83). Pada dasarnya belajar dalam persepektif kognitif merupakan peristiwa mental, bukan peristiwa yang bersifat jasmaniah meskipun hal-hal yang bersifat jasmaniah tampak lebih nyata dalam peristiwa belajar mengajar (Syah, 2013: 109).

Metode card sort dengan menggunakan media kartu dalam praktek pembelajaran, akan membantu siswa dalam memahami pelajaran dan menumbuhkan motivasi dan kemampuan mereka dalam pembelajaran, sebab dalam penerapan metode card sort, guru hanya berperan sebagai fasilitator, yang memfasilitasi siswanya dalam pembelajaran, sementara siswa belajar secara aktif dengan fasilitas dan arahan dari guru, sehingga yang aktif disini bukan guru melainkan siswa itu sendiri yang harus aktif dalam pembelajaran.

Aplikasi metode card sort seperti yang dijelaskan sebelumnya, lebih melibatkan siswa dalam kegiatan belajar yang aktif, siswa diharapkan mempunyai motivasi belajar yang lebih tinggi dan terus meningkatkan kemampuan belajar siswa, sehingga siswa dapat belajar dengan lebih mandiri, berfikir kritis dan kreatif dalam menyelesaikan tugas yang diberikan. Munculnya motivasi dan kemampuan belajar siswa dapat menumbuhkan percaya diri, karena dapat menyelesaikan pekerjaannya dengan baik, siswa akan lebih senang dan akan memberikan dorongan untuk selalu mengingat materi pelajaran yang telah disampaikan (Fakhrurrazi, 2016: 90-91). Berdasarkan permasalahan mengenai pembelajaran yang intruksional dan sekedar hafalan, maka peneliti akan menganalisis metode card sort dalam pembelajaran mufrodat bahasa Arab berbasis pendekatan kognitif.

\section{METODE PENELITIAN}

Pengumpulan data dalam penelitian ini menggunakan penelitian kualitatif menepati peran yang sangat penting. Kualitas hasil temuan dalam penelitian kualitatif sangat ditentukan oleh cara pengumpulan data. Dalam penelitian kualitatif kehadiran peneliti sewaktu mengumpulkan data sangat 
berguna untuk membantu menganalisa dan menginterpretasikan data yang terkumpul. Kreatifitas peneliti memegang peran yang penting walaupun kreatifitas tersebut bersifat pribadi (Setiyadi, 2006: 237).

Jenis pendekatan menggunakan kepustakaan (library research), studi pustaka atau kepustakaan dapat diartikan sebagai serangkaian kegiatan yang berkenaan dengan metode pengumpulan data pustaka, membaca dan mencatat serta mengolah bahan penelitian (Zed, 2003: 3). Telaah pustaka (library reseach) dapat saja sebatas ringkasan dari sejumlah sumber rujukan, namun telaah pustaka disusun dengan pola oraginasasi tertentu yang dikombinasikan dengan ringkas dan sintesis. (Gumanti, Yunidar, \& Syahruddin, 2016: 89). Adapun dalam peneletian ini sumber yang digunakan dari berbagai jurnal-jurnal dan buku-buku serta sumber lainya yang relevan.

\section{HASIL DAN PEMBAHASAN Mufradat}

Mufradat merupakan salah satu unsur bahasa yang harus dimiliki oleh pembelajar bahasa asing termasuk bahasa Arab. Perbendaharaan mufradat bahasa Arab yang memadai dapat menunjang seseorang dalam berkomunikasi dan menulis dengan bahasa tersebut. Dengan demikian, dapat dikatakan bahwa berbicara dan menulis yang merupakan kemahiran berbahasa tidak dapat tidak, harus didukung oleh pengetahuan dan penguasaan mufradat yang kaya, produktif dan aktual.

Menurut Horn, bahwa mufradat adalah sekumpulan kata yang membentuk sebuah bahasa. Peran mufradat dalam menguasai empat kemahiran berbahasa sangat diperlukan sebagaimana yang dinyatakan Vallet adalah bahwa kemampuan untuk memahami empat kemahiran berbahasa tersebut sangat bergantung pada penguasaan mufradat seseorang. Meskipun demikian pembelajaran bahasa tidak identik dengan hanya mempelajari mufradat. Dalam arti untuk memiliki kemahiran berbahasa tidak cukup hanya dengan menghafal sekian banyak mufradat (Hijriyyah, 2018: 22-24).

Mufradat merupakan kumpulan katakata tertentu yang akan membentuk bahasa. Kata adalah bagian terkecil dari bahasa yang sifatnya bebas. Pengertian ini membedakan antara kata dengan morfem. Morfem adalah satuan bahasa terkecil yang tidak bisa dibagi atas bagian bermakna yang lebih kecil yang maknanya relative stabil. Maka kata terdiri dari morfem-morfem, misalnya kata mu'allim sealam bahasa Arab terdiri dari satu morfem. Sedangkan kata al-mu'allim المعلم

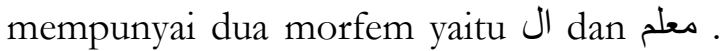
Adapun kata yang mempunyai tiga morfem adalah kata yang terbentuk dari morfemmorfem yang mana masing-masing morfem mempunyai arti khusus. Misalnya kata almu'allimun المعلمون yang terdiri dari tiga

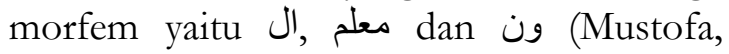
2011: 21).

Thu'aimah memberikan klasifikasi mufradat menjadi 4 (empat) yang masingmasing terbagi lagi sesuai dengan tugas dan fungsinya, sebagai berikut.

1. Pembagian mufradat dalam konteks kemahiran kebahasaan

a. Mufradat untuk memahami baik bahasa lisan (istima') maupun teks (qira'ah).

b. Mufradat untuk berbicara. Dalam pembicaraan perlu penggunaan mufradat yang tepat, baik pembicaraan informal maupun formal.

c. Mufradat untuk menulis. Penulisan pun membutuhkan pemilihan mufradat yang baik dan tepat agar tidak disalah artikan oleh pembacanya. Penulisan ini mencakup penulisan informal seperti catatan harian, agenda harian dan lain-lain dan juga formal, misalnya penulisan buku, majalah, surat kabar dan seterusnya.

d. Mufradat potensial. Mufradat jenis ini terdiri dari mufradat context yang dapat diinterpretasikan sesuai 
dengan konteks pembahasan, dan mufradat analysis yakni mufradat yang dapat dianalisa berdasarkan karakteristik derivasi kata unuk selanjutnya dipersempit atau diperluas maknanya.

2. Pembagian mufradat menurut maknanya

a. Mufradat inti. Mufradat ini adalah mufradat dasar yang membentuk sebuah tulisan menjadi valid, misalnya kata benda, kata kerja, dan lain-lain.

b. Mufradat fungsi. Mufradat ini yang mengikat dan menyatukan mufradat dan kalimat sehingga menbentuk paparan yang baik dalam sebuh tulisan. Contohnya burûf jâr, adawât al-istifhâm, dan seterusnya.

c. Mufradat gabungan. Mufradat ini adalah mufradat yang tidak dapat berdiri sendiri, tetapi selalu dipadukan dengan kata-kata lain sehingga membentuk arti yang رغب berbeda-beda. Misalnya kata dapat berarti menyukai bila kata tersebut dipadukan dengan في menjadi Sedangkan bila رغب menjadi عن في في ع artinya pun berubah menjadi benci atau tidak suka. (Hijriyyah, 2018: 28-30).

3. Pembagian mufradat menurut karakteristik kata (takhassus)

a. Mufradat tugas yaitu mufradat yang digunakan untuk menunjukan tugas, baik dalam lapangan kehidupan secara informal maupun formal dan sifatnya resmi.

b. Mufradat inti khusus. Mufradat ini adalah kumpulan kata yang dapat mengalihkan arti kepada yang spesifik dan digunakan di berbagai bidang ulasan tertentu.

4. Pembagian mufradat menurut penggunaannya

a. Mufradat aktif, yakni mufradat yang umumnya banyak digunakan dalam berbagai wacana, baik pembicaraan, tulisan atau bahkan banyak didengar dan diketahui lewat berbagai bacaan.

b. Mufradat pasif, yaitu mufradat yang hanya menjadi perbendaharaan kata seseorang namun jarang ia gunakan. Mufradat ini diketahui lewat bukubuku cetak yang biasa menjadi rujukan dalam penulisan makalah atau karya ilmiah. (Mu'at, 2013: 8586)

Mufradat sebagai salah satu bagaian penting dari komponen bahasa, baik penggunaan bahasa secara lisan maupun secara tertulis, dan merupakan salah satu basis pengembangan kemampuan berbahasa Arab. Diantara tujuan utama pembelajaran mufradat bahasa Arab adalah sebagai berikut:

1. Memperkenalkan mufradat baru kepada siswa, baik melalui bahan bacaan maupun pendengaran.

2. Melatih siswa untuk dapat melafalkan mufradat itu dengan baik dan benar karena pelafalan yang baik dan benar mengantarkan kepada kemahiran berbicara dan membaca secara baik.

3. Memahami makna mufradat, baik secara denotative atau leksikal maupun ketika digunakan dalam konteks kalimat tertentu (makna konotatif dan gramatikal).

4. Mampu mengapresiasi dan memfungsikan mufrodat itu dalam ekspresi lisan (berbicara) maupun tulisan (mengarang) sesuai dengan konteksnya yang benar (Hamid, 2010: 33).

\section{Metode Card Sort}

Metode card sort adalah metode pembelajaran yang mengajak peserta didik agar mempunyai jiwa yang mandiri sehingga dapat meningkatkan kreativitas peserta didik untuk membuat inovasi dalam pembelajaran. Metode ini merupakan metode pembelajaran melalui permainan sehingga dapat menarik minat siswa untuk 
belajar. Melalui permainan siswa akan berkembang dalam segi perkembangan berpikirnya maupun kemampuan mengontrol emosi serta melakukan sosialisasi dengan siswa lain dalam kelas, sehingga dapat digunakan untuk mengajarkan konsep, penggolongan sifat, fakta tentang suatu obyek atau mengulangi informasi (Baidlowi, 2016: 113).
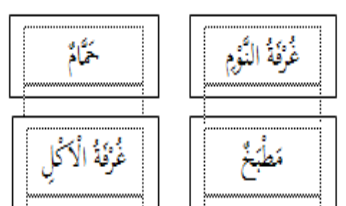

Menurut Yasin yaitu suatu strategi yang digunakan pendidik dengan maksud mengajak peserta didik untuk menemukan konsep dan fakta melalui klasifikasi materi yang dibahas dalam pembelajaran. Seorang guru dengan maksud mengajak peserta didik untuk menemukan konsep dan fakta melalui kalsikafikasi materi yang dibahas dalam pembelajaran. Langkah-langkah penerapanya:

1. Bagikan kertas yang bertuliskan informasi atau kategori tertentu secara acak.

2. Tempelkan kategori utama di papan tulis atau kertas di dinding kelas.

3. Mintalah peserta didik untuk mencari temannya yang memiliki kertas atau kartu yang berisi tulisan yang sama untuk membentuk kelompok dan mendiskusikanya.

4. Mintalah mereka untuk mempresentasikanya.

Fakhurrazi (2016: 93-94) menjelaskan bahwa metode card sort, dengan menggunakan media kartu dalam praktek pembelajaran, akan membantu siswa dalam memahami pelajaran dan menumbuhkan motivasi dan kemampuan mereka dalam pembelajaran, sebab dalam penerapan metode card sort, guru hanya berperan sebagai fasilitator, yang memfasilitasi siswanya dalam pembelajaran, sementara siswa belajar secara aktif dengan fasilitas dan arahan dari guru, sehingga yang aktif disini bukan guru melainkan siswa itu sendiri yang harus aktif dalam pembelajaran. Tujuan dari strategi dan metode belajar menggunakan "memilah dan memilih kartu "card sort" ini adalah untuk mengungkapkan daya "ingat" terhadap materi pelajaran yang telah dipelajari siswa. Sehingga siswa benarbenar memahami dan mengingat pelajaran yang telah diberikan. Hal-hal yang perlu diperhatikan adalah:

1. Kartu-kartu tersebut jangan diberi nomor urut

2. Kartu-kartu tersebut dibuat dalam ukuran yang sama

3. Jangan memberi "tanda kode" apapun pada kartu-kartu tersebut

4. Kartu-kartu tersebut terdiri dari "beberapa bahasan" dan dibuat dalam jumlah yang banyak atau sesuai dengan jumlah siswa.

5. Materi yang ditulis dalam kartu-kartu tersebut, telah diajarkan dan telah dipelajari oleh mahasiswa atau siswa.

\section{Pendekatan Kognitif}

Pandangan Gestalt tentang belajar dinyatakan dalam konsep pembelajaran yang disebut teori kognitif. Dua kunci pendekatan kognitif adalah bahwa sistem ingatan merupakan suatu prosesor informasi yang aktif dan terorganisasi, bahwa pengetahuan awal memerankan penting dalam pembelajaran. Teori kognitif mencermati hal-hal dibalik perilaku untuk menjelaskan pembelajaran berbasis otak (brain-based learning).

Teori kognitif lebih mementingkan proses belajar dari pada hasil belajar. Teori menekankan bahwa perilaku seseorang ditentukan oleh persepsi serta pemahamannya tentang situasi yang berhubungan dengan tujuan belajarnya. Teori ini berpandangan bahwa belajar merupakan suatu proses internal yang mencakup ingatan, retensi, pengolahan informasi, emosi dan aspek kejiwaan lainya. Belajar berupa aktivitas yang melibatkan 
proses berfikir yang sangat kompleks (Suyono, 2012: 75).

Menurut Pieget (Suyono \& Hariyanto, 2012: 82-83), perkembangan kognitif merupakan suatu proses genetic yaitu suatu proses yang didasarkan atas mekanisme biologis perkembangan system saraf. Dengan makin bertambahnya usia seseorang, maka makin komplekslah susunan sel sarafnya dan makin meningkat pula kemampuannya. Menurut Piaget (Hamdayama, 2016: 39), proses belajar yang sebenarnya terdiri dari tiga tahapan, yakni asimilasi, akomodasi, dan equilibrasi (penyeimbangan).

Dalam dunia nyata melibatkan penggunaan proses kognitif, meliputi perencanaan penuh untuk berfikir (menggunakan waktu untuk berfikir dan merencanakan), berfikir secara menyeluruh (terbuka dengan berbagai gagasan dan menggunakan perspektif yang beragam), berfikir secara sistematik (diatur, menyeluruh, dan sistematik), berfikir analitik (pengklasifikasian, analisis, logis, dan kesimpulan), berfikir analogis (mengaplikasikanpersamaan, pola, berfikir paralel, dan lateral), berfikir system ( holistic dan berfikir menyeluruh) (Rusman, 2012: 235).

Teori Gestalt bentuk yang dikembangkan diantaranya oleh Max Wertheir seorang psikolog Jerman, Koffa, dan Kohler. Inti dari teori Gestalt yang dirangkum dari berbagai sumber adalah sebagai berikut:

1. Jika aliran behavioristic yang memandang belajar sebagai perilaku mekanistis tanpa adanya peran insight, teori Gestalt yang merupakan kelompok aliran kognitif holistic memandang belajar adalah proses mengembangkan insight atau memahami hubungan antara unsur dalam suatu masalah. Insight yang diperoleh dari pemecahan masalah tertentu suatu saat kelak dapat digunakan untuk memecahkan masalah dalam situasi lain.
2. Masalah yang dihadapi oleh seseorang akan menimbulkan ketidakseimbangan kognisi dan orang itu akan berusaha memecahkan masalah tersebut guna mencapai kembali keseimbangan kognisi.

3. Belajar didasarkan pada pengalaman atau pengorganisasian kembali pengalaman-pengalaman masa lalu yang secara terus menerus disempurnakan. Oleh sebab itu pengalaman dapat memberikan arti dalam kehidupan seseorang (Gintings, 2010: 25).

Teori belajar kognitif memandang bahwa pengetahuan tidak dapat dipindahkan begitu saja dari pikiran guru ke pikiran siswa. Akan, tetapi siswa harus aktif secara mental dan fisik membangun struktur kognitif pengetahuanya berdasarkan tingkat kematangan kognitif yang dimilikinya. Aktifitas secara fisik pada siswa berarti secara aktif membangun konsep pengetahuannya melalui aktifitas pengalaman fisik secara konkret. Pembelajarn dalam pandangan kognitif lebih menekankan proses yang berpusat pada siswa serta berorientasi pada pembentukan pengetahuan dan penalaran siswa. Hal ini disebabkan misi pembelajaran kognitif adalah meningkatkan dan membangun kemampuan siswa dalam memperoleh, menganalisis, dan mengolah informasi secara cermat serta menumbuhkan kemampuan siswa dalam memecahkan masalah.

Sementara menurut Sugihartono (Irham \& Wiyani, 2013: 180-181), proses pembelajaran dan pendidikan dalam pandangan teori belajar kognitif menekankan pada tercapainya beberapa tujuan pembelajaran dan pendidikan itu sendiri.

1. Menghasilkan individu siswa yang memiliki kemampuan berfikir untuk menyelesaikan masalah yang dihadapinya. 
2. Peserta didik diharapkan aktif dalam kegiatan belajar sesuai karakteristik dirinya dalam belajar.

3. Guru berperan sebagai mediator, fasilitator, dalam proses kontruksi pengetahuan siswa.

Analisis Metode Card Sort dalam Pembelajaran Mufradat Bahasa Arab Berbasis Pendekatan Kognitif

Proses belajar mengajar senantiasa merupakan proses kegiatan interaksi antara dua unsur manusiawi, yakni siswa sebagai pihak yang belajar dan guru sebagai pihak yang mengajar, dengan siswa sebagai subyek pokoknya. Dalam interaksi belajar mengajar, seorang guru sebagai pengajar akan berusaha secara maksimal dengan menggunakan berbagai keterampilan dan kemampuannya agar anak didik dapat mencapai tujuan yang diharapkan. Proses belajar harus tumbuh dan berkembang dari diri anak itu sendiri, dengan kata lain anakanak yang harus aktif belajar sedangkan guru bertindak sebagai pembimbing. Soetomo mengatakan bahwa "interaksi belajar mengajar merupakan suatu kegiatan yang berproses antara guru dan murid, dimana guru melaksanakan pengajaran dan murid dalam keadaan belajar" (Fathurrahman, 2012: 24-28).

Hal tersebut senada dengan teori kognitif yang dinyatakan oleh Gestalt lebih mementingkan proses belajar dari pada hasil belajar. Teori menekankan bahwa perilaku seseorang ditentukan oleh pemahamannya tentang situasi yang berhubungan dengan tujuan belajar. Teori ini berpandangan bahwa belajar merupakan suatu proses internal yang mencakup ingatan, retensi, pengolahan informasi, emosi dan aspek kejiwaan lainya. Belajar merupakan aktivitas yang melibatkan proses berfikir yang sangat kompleks (Suyono \& Hariyanto, 2012: 75).

Dalam proses pengajaran guru di sekolah (di kelas) peranan guru lebih spesifik sifatnya dalam pengertian yang sempit yakni dalam hubungan proses belajar mengajar. Sebagai fasilitator, guru berperan sebagai pembantu dalam pengalaman belajar, membantu perubahan lingkungan, serta membantu terjadinya proses belajar yang serasi dengan kebutuhan dan keinginan (Hamalik, 2008: 47-49). Metode, cara atau teknik pengajaran merupakan komponen proses belajar mengajar yang banyak menentukan keberhasilan pengajaran. Secara umum metode diartikan sebagai cara melakukan sesuatu, sedangkan secara khusus, metode pembelajaran dapat diartikan sebagai "cara atau pola yang khas dalam memanfaatkan berbagai prinsip dasar pendidikan serta berbagai teknik dan sumber daya terkait lainya agar terjadi proses pembelajaran pada diri pembelajar. (Fathurrahman, 2012:49) Metode card sort merupakan kegiatan kolaboratif yang bisa digunakan untuk mengajarkan konsep, karakteristik, klasifikasi, fakta, tentang obyek informasi. Gerakan fisik yang dominan dalam strategi ini dapat membantu mendinamiskan kelas yang jenuh atau bosan. Langkah-langkahnya:

1. Setiap peserta didik diberi potongan kertas yang berisi mufradat.

2. Mintalah peserta didik untuk bergerak dan berkeliling didalam kelas untuk menemukan kartu dengan kategori mufradat yang sama. (pendidik dapat mengumumkan kategori sebelumnya atau membiarkan peserta didik menemukanya sendiri).

3. Peserta didik dengan kategori mufradat yang sama diminta untuk membacakan serta menerangkan makna mufradat masing-masing di depan kelas.

4. Seiring dengan membacakan serta menerangkan makna dari tiap-tiap kategori mufradat tersebut, berikan poin-poin penting terkait materi pelajaran (Zaini, Munthe, \& Aryani, 2008: 50-51).

Mufrodat sebagai salah satu bagian penting dari komponen bahasa, baik penggunaan bahasa secara lisan maupun secara tertulis. Diantara tujuan utama 
pembelajaran mufrodat bahasa Arab adalah pertama, memperkenalkan mufradat baru kepada siswa, baik melalui bahan bacaan maupun pendengaran. Kedua, melatih siswa untuk dapat melafalkan mufradat itu dengan baik dan benar karena pelafalan yang baik dan benar mengantarkan kepada kemahiran berbicara dan membaca secara baik. Ketiga, memahami makna mufradat, baik secara denotative atau leksikal maupun ketika digunakan dalam konteks kalimat tertentu (makna konotatif dan gramatikal). Keempat, mampu mengapresiasi dan memfungsikan mufrodat itu dalam ekspresi berbicara maupun mengarang sesuai dengan konteksnya yang benar (Hamid, 2010: 33).

Menurut Pieget bahwa anak membangun sendiri skemata-skemata dari pengalaman sendiri dengan lingkunganya. Disini peran guru sebagai fasilitator dan bukan sebagai pemberi informasi. Guru perlu menciptakan lingkungan yang kondusif bagi para siswanya. Guru dapat menciptakan suatu keadaan atau lingkungan belajar yang memadai agar siswa dapat menemukan pengalaman-pengalaman nyata dan terlibat langsung. Peranan guru sangat penting untuk menciptakan situasi belajar sesuai dengan teori Piaget, beberapa implikasi teori Piaget dalam pembelajaran, sebagai berikut:

1. Memfokuskan pada proses berpikir anak, tidak sekedar pada produknya.

2. Pengenalan dan pengakuan atas peranan anak-anak yang penting sekali dalam inisiatif diri dan keterlibatan aktif dalam kegiatan pembelajaran.

3. Penerimaan perbedaan individu dalam kemajuan perkembangan. Bahwa seluruh anak berkembang melalui urutan perkembangan yang sama namun mereka memperolehnya pada kecepatan yang berbeda.

Dari implikasi teori peaget tersebut, jelaslah guru harus mampu menciptakan keadaan pembelajar yang mampu untuk belajar sendiri. Artinya, guru tidak sepenuhnya mengajarkan suatu bahan ajar kepada pembelajar, tetapi guru dapat membangun pembelajar yang mampu belajar dan terlibat aktif dalam belajar. (Trianto, 2010: 72-73), khususnya dalam pembelajaran mufradat dengan menggunakan motode card sort maka seorang siswa lebih aktif dalam belajarnya.

\section{SIMPULAN}

Teori kognitif menurut pandangan Gestalt dan Piaget lebih mementingkan proses dalam belajar dari pada hasil belajar. Teori ini menekankan bahwa perilaku seseorang ditentukan oleh pemahamannya tentang situasi yang berhubungan dengan tujuan belajar. Dalam pembelajaran mufrodat bahasa arab, seorang guru dalam proses belajar mengajar menggunakan metode card sort, agar para peserta didik terlihat tidak jenuh dan monoton, peserta didik diharapkan lebih aktif dalam mengikuti pembelajaran, karena dalam intinya pendekatan kognitif peserta didik yang mengeksplorasikan, berfikir dan memahami sendiri. Sehingga dalam hal ini pembelajaran berpusat pada peserta didik (student center), sedangkan guru adalah sebagai fasilitator dalam proses pembelajaran mufradat bahasa Arab.

\section{DAFTAR RUJUKAN}

Astuti, W. 2016. Berbagai Strategi Pembelajaran Kosa Kata Bahasa Arab. Jurnal Komunikasi dan Pendidikan Islam, 5 (2), 177-191.

Baidlowi. 2016. Peningkatan kualitas Pembelajaran PAI Melalui Metode Card Sort pada Siswa Kelas III SD Negeri 3 Batur Agung Kecamatan Gubug Kabupaten Grobogan. Refleksi Edukatika: Jurnal Ilmiah Kependidikan, 6 (2), 112-118.

Fajriah, Z. 2015. Peningkatan Penguasaan Kosa Kata Bahasa Arab Melalui Penggunaan Media Kartu Bergambar. Jurnal Pendidikan Usia Dini, 9 (1), 107126. 
Fakhrurrazi. 2016. Penerapan Metode Card Sort dalam Peningkatan Motivasi dan Kemampuan Belajar Siswa Bidang Studi Qur'an Hadits pada Siswa Mts Darul Huda Kota Langsa. Al-Ikbtibar: Jurnal Ilmu Pendidikan, 3 (2), 87-101.

Fathurrahman, M. \& Sulistiyorini. 2012. Belajar dan Pembelajaran. Yogyakarta: Teras.

Gintings, A. 2010. Belajar dan Pembelajaran. Bandung: Humaniora.

Gumanti, T. A., Yunidar, \& Syahruddin. 2016. Metodologi Penelitian Pendidikan. Jakarta: Mitra Wacana Media.

Hamalik, O. 2008. Perencanaan Pengajaran Berdasarkan Pendekatan System. Jakarta: Bumi Aksara.

Hamdayama, J. 2016. Metodologi Pengajaran. Jakarta: Bumi Aksara.

Hamid, A. 2010. Mengukur Kemampuan Babasa Arab untuk Studi Islam. Malang: UIN-Maliki Press.

Hartono. 2011. Pendidikan Integrasi, Purwokerto: Stain Pres.

Hijriyah, U. 2018. Analisis Pembelajaran Mufrodat dan Struktur Bahasa Arab di Madrasab Ibtidaiyah. Surabaya: CV. Gemilang.

Irham, M. \& Wiyani, N. A. (2013). Psikologi Pendidikan. Yogyakarta: Ar-Ruzz Media.

Maksudin \& Nurani, Q. (2018). Pengembangan Kurikulum Pembelajaran Babasa Arab. Yogyakarta: Pasca FITK UIN-SUKA.

Mu'at. 2013. Strategi Pembelajaran Kosakat (Mufradat) Bahasa Arab. Al Ta'dib, 3 (1), 81-99.

Mustofa, S. 2011. Strategi Pembelajaran Bahasa Arab Inovatif. Malang: UIN Press.
Qomaruddin, A. 2017. Implementasi Metode Bernyanyi dalam Pembelajaran Mufradat. Jurnal Kependidikan, 5 (1), 2021.

Rosyidi, A. W. 2009. Media Pembelajaran Bahasa Arab. Malang: UIN-Malang Press.

Rusman. 2012. Model-Model Pembelajaran. Jakarta: Rajagrafindo Persada.

Sanjaya, W. 2008. Strategi Pembelajaran Berorientasi Standar Proses Pendidikan. Jakarta: Kencana.

Setiyadi, B. 2006. Metode Penelitian Untuke Pengajaran Bahasa Asing. Yogyakarta: Graha Ilmu.

Suprihatin, E., Elmubarok, Z. \& Busri, H. 2017. Pengaruh Menghafal Al-Qur'an Juz 29 Terhadap Penguasaan Kosa Kata dan Keterampilan Membaca Bahasa Arab Kelas. Jurnal Linasul Arab, $6(1), 38-43$.

Suyono \& Hariyanto. 2012. Belajar dan Pembelajaran. Bandung: Remaja Rosda Karya.

Syah, M. 2013. Psikologi Pendidikan. Bandung: Remaja Rosda Karya.

Trianto. 2010. Model Pembelajaran Terpadu. Jakarta: Bumi Aksara.

Yasin, F. 2018. Dimensi-Dimensi Pendidikan Islam, Malang: UIN-Malang Press.

Zaini, H., Munthe, B., \& Aryani, S. A. 2008. Strategi Pembelajaran Aktif, Yogyakarta: Pustaka Insan Madani.

Zed, M. 2003. Metode Penelitian Kepustakaan, Jakarta: Yayasan Obor.

Zulhannan \& Rahayu, S. 2014. Teknike Pembelajaran Bahasa Arab Interaktif. Jakarta: Grafindo Persada. 